\title{
PBL: An Effective Method of Reinforcement Learning
}

\section{Montosh Chakraborty ${ }^{1}$, Shivakrishna Gouroju *2, Pinki Garg ${ }^{3}$, Karthikeyan P 4.}

${ }^{1}$ Assistant Professor, Department of Biochemistry, Andaman and Nicobar Islands Institute of Medical Sciences, Port Blair, India.

${ }^{* 2}$ Tutor in Department of Biochemistry, Andaman and Nicobar Islands Institute of M edical Sciences, Port Blair, India.

${ }^{3}$ Assistant Professor, Department of Biochemistry, NDM C M edical college, Delhi, India.

${ }^{4}$ PG Trainee, Department of Biochemistry, M aulana Azad M edical College, New Delhi, India.

\section{ABSTRACT}

The teaching method in undergraduate M BBS curricula is expected to develop a vast range of intellectual, visual and manual skills, in the learning and incorporate large amounts of factual information to practice technical and technological procedures. Problem based learning (PBL) is small group teaching and learning program, which emphasizes and stimulates the team work and problem solving ability, independent learning and create a broader understanding of the complexity of medicine. The students must become proficient in assessing their individual learning progress and that of their peers. So our study aims to evaluate the efficiency of PBL in the enhancement of knowledge of 126 learners. We measured the student preference regarding PBL system. The participants were divided into 2 groups on the basis of before theory and after theory test marks and were sex matched. After that group-I attended revision of theory class and group-II attended PBL class with the same teacher on the same topic. After revision theory class and the PBL session, learner's response was increased significantly when compared with before and after theory class. When we compared PBL with after theory revision class the learning knowledge was significantly increased ( $p$-values 0.00 ). Students who used the problem-based learning method showed better understanding of the subject and it also encouraged active student participation in the learning process.

KEY WORDS: Problem based learning, traditional learning, teaching.

Address for correspondence: Shivakrishna Gouroju, Tutor in Department of Biochemistry, Andaman and Nicobar Islands Institute of M edical Sciences, Port Blair, India.

E-M ail: phdbiochemshiv@gmail.com

\begin{tabular}{|c|c|c|}
\hline \multicolumn{3}{|c|}{ Online Access and Article Informtaion } \\
\hline $\begin{array}{l}\text { Quick Response code } \\
\text { 口 }\end{array}$ & \multicolumn{2}{|c|}{$\begin{array}{l}\text { International Journal of Integrative Medical Sciences } \\
\text { www.imedsciences.com }\end{array}$} \\
\hline Dol: 10.16965 ijims.2015.119 & $\begin{array}{l}\text { Received: 15-06-2015 } \\
\text { Reviewed: 15-06-2015 }\end{array}$ & $\begin{array}{l}\text { Accepted: } \mathbf{2 4 - 0 6 - 2 0 1 5} \\
\text { Published: } 30-06-2015\end{array}$ \\
\hline Source of Funding: Self & \multicolumn{2}{|c|}{ Conflicts of interest: None } \\
\hline
\end{tabular}

\section{INTRODUCTION}

In modern days, learning a biomedical profession is an increasing challenge. The learners is required to develop a vast range of intellectual, visual and manual skills, to take into account large amounts of factual information and to practice technical and technological procedures. Along with the traditional lectures and self-guided individual learning, biomedical educators are encouraged to find and implement ways to promote higher order thinking, collaborative learning and to increase students' motivation [1]. Along with the traditional teaching, new learning methods are being explored. Ex: Case Based Learning (CBL), Problem Based Learning (PBL) or Simulation Based Training (SBT) study is evaluated as an effective teaching method for the learners. The PBL is small group teaching and learning program, which stimulates team work and problem solving ability of the 
learners [2]. It is also called open enquiry approach. The traditional lecture based educational approaches gives the basic knowledge on the problem. On the contrary to traditional methods, facilitators play minimal role and do not guide discussion, even when learners explore tangents. The learners are presented a problem, often based on the clinical signs as a starting point for discussion and struggle, define the problem explore related issues and grapple with problem resolution. Basically PBL has demonstracted improved learning capacity and satisfactiory changes in the evaluation test score from the responses to multiple choice questions [3].

PBL proponents argue that PBL methods encourage lifelong learning, simulate clinical practice, encourage curiosity, and create a broader understanding of the complexity of medicine $[4,5]$. PBL detractors argue that the PBL process is time inefficient, frustrating for time pressured medical learners, and often leads to erroneous conclusions [6]. Additionally, there is little guarantee that the students will learn how to apply the material necessary for clinical practice in the absence of appropriate clinical direction. PBL detractors also state that the presence and expertise of the faculty is wasted if it not harnessed in more than a passive manner. The findings of this methodology can be traced back to Dewey [7], an early educational philosopher, who suggested that, students should be presented with real life problems and then, helped to discover the information required to solve them. Furthermore, Dewey encouraged reflection as a process that should be used when problem solving. The author recognized that we can "reflect" on a whole host of things in the sense of merely "thinking about" them; however, logical or analytical reflection can take place only when there is a real problem to be solved [8]. M cM aster University recognized the importance of Dewey's axiom for medical education, and created a curriculum that applied the PBL approach to teach medical students [9]. At this point we should cite Barrows [10], who argued that, "the term problem-based learning must be considered a genus for which there are many species and subspecies." In the PBL approach developed at M cM aster University, students are first presented with the patient's problem. Next, the learners engaged in several processes, like hypothesis generation, data gathering, data analysis and decision-making, while synthesizing basic science and clinical information, in an effort to offer some potential diagnoses and courses of treatment for the patient's problem [8]. In PBL, instead of a lecturer, we have an expert tutor or facilitator to guide the problem-solving process. All methodologies regarding real problems stand in contrast to a more traditional approach to learning and instruction. They promote learnercentered, small group, interactive learning experiences, instead of large group, didactic, teacher-centered instruction. As such, students are free to pursue determined learning issues, both collectively and individually, in contrast to students in more traditional curricula who might focus on identifying what material the professor will include on the exam [8]. Finally, the assessments in PBL typically include performance-based and self-reflective assessments, while traditional approaches to instruction often emphasize multiple choices, objective tests [11]. With these models of instruction, it is expected that students readily re-organize and apply knowledge in response to various situational demands. To attain this flexibility, students must understand the problems in their full complexity and reorganize them, several times, to observe how shifts in variables and goals alter the outcomes. How well one can perform at this level, is a function of both the way knowledge is represented and the processes that operate on those mental representations. This perspective can be supported in Cognitive Flexibility and Social Constructivism learning approaches.

Although a major component of the assessment of students' progress comes from self and peer assessment that occurs at the end of every problem, additional formal assessments must assess the students' problem-solving skills, selfdirected learning skills, clinical skills and ability to recall and apply an integrated knowledge base in work with a problem. The students must become proficient in assessing their individual learning progress and that of their peers. So in 
this study an effort was made to estimate the impact of PBL as a knowledge enhancement tool in comparison to traditional teaching methods.

\section{MATERIALS AND METHODS}

The PBL program is a case control study conducted by the Department of Biochemistry Department, Maulana Azad M edical College, New Delhi, India. The program scheduled was traditional lecture class and PBL class. We conducted an evaluation test of 20 marks multiple choice questions before lecture class and after lecture class with the same question paper. Based on the marks obtained in the exams we divided total participants into 2 groups and were sex matched. The mean of the two groups are almost equal (table no.3). In group-I 63 students ( 28 females, 35 males) attended revision theory class (theory class 2) and group-II consisting of 63 students ( 28 females, 35 males) attended PBL class. After that both the groups attended the evaluation test with the same question paper. The results were given on the next day of the program.

\section{RESULTS AND TABLES}

A total of 126 learners including 56 (44.4\%) females and $70(55.6 \%)$ male students were part of the study. The learners reveal that the PBL system helps developing student skills including: problem solving skills, sharpening of analytical skills, helping them to work as team member. Almost all the Learners agreed that PBL system help them to develop their ability to plan their own work. Students revealed that there is a lot of pressure on them to do well in the course. We measured the student performance after $2^{\text {nd }}$ theory class and PBL Class. After $2^{\text {nd }}$ theory class the learners scored $63.81 \%$, earlier it was $38.41 \%$ (before theory) and $57.22 \%$ (after theory). After the PBL, the learners scored $78.7 \%$

Table 1: Shows the percentage (\%) of marks obtained in the test.

\begin{tabular}{|c|c|c|c|c|}
\hline & $\begin{array}{c}\text { Before } \\
\text { theory }\end{array}$ & $\begin{array}{c}\text { After } \\
\text { theory }\end{array}$ & $\begin{array}{c}\text { After 2 } \\
\text { theory }\end{array}$ & Post PBL \\
\hline Total \% & 38.33 & 56.83 & - & - \\
\hline Group-1\% & 38.41 & 57.22 & 63.81 & - \\
\hline Group-II \% & 38.25 & 56.43 & - & 78.7 \\
\hline
\end{tabular}

which was $38.25 \%$ earlier (before theory) and $56.43 \%$ (after theory). Thus, Group-II which attended PBL class showed higher percentage of marks than Group-l.

Table 2: shows the MEANS and SD of total participants' marks before and after theory.

\begin{tabular}{|c|c|c|}
\hline & Mean & SD \\
\hline Before theory & 7.67 & 1.62 \\
\hline After theory & 11.37 & 1.97 \\
\hline
\end{tabular}

Graph 1: Showing the range of total participants before and after theory.

BEFORE THEORY

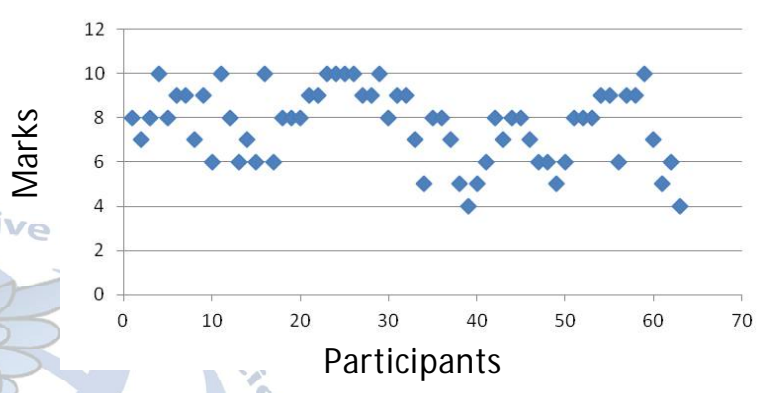

AFTER THEORY

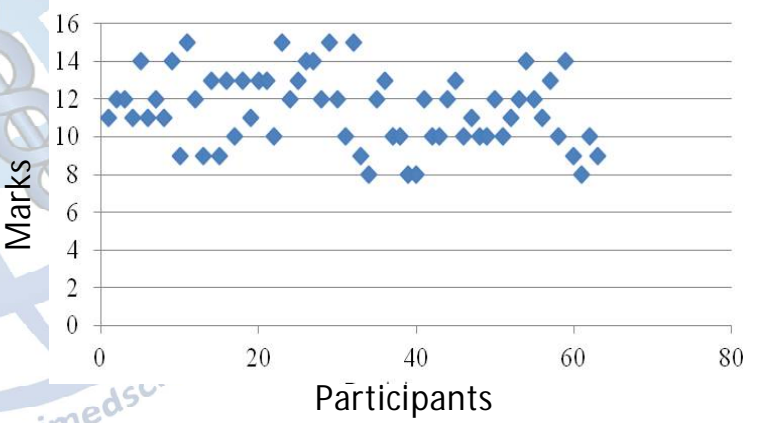

Table 3: Shows the MEANS and SD of marks obtained Before theory, After theory, After $2^{\text {nd }}$ theory, and post PBL in Group-I and II.

\begin{tabular}{|c|c|c|c|}
\hline & & Mean & SD \\
\hline \multirow{3}{*}{ Group-I } & Before theory & 7.68 & 1.64 \\
\cline { 2 - 4 } & After theory & 11.44 & 1.92 \\
\cline { 2 - 4 } & After 2 theory & 12.76 & 1.7 \\
\hline \multirow{3}{*}{ Group-II } & Before theory & 7.65 & 1.62 \\
\cline { 2 - 4 } & After theory & 11.29 & 2.04 \\
\cline { 2 - 4 } & PBL & 15.75 & 1.19 \\
\hline
\end{tabular}

Graph 2: Shows the M EANS and SD of marks obtained Before theory, After theory, After $2^{\text {nd }}$ theory, and post PBL in Group-I and II.

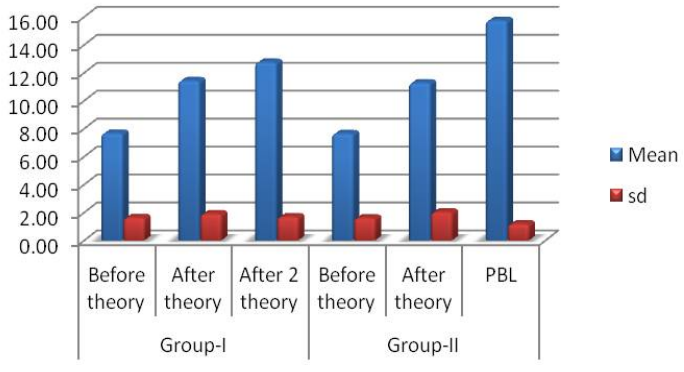


Table 4: Shows the p-values of Group-I and II.

\begin{tabular}{|c|l|c|}
\hline & \multicolumn{1}{|c|}{} & p values \\
\hline \multirow{4}{*}{ Group-I } & $\begin{array}{l}\text { After theory compared with } \\
\text { before theory }\end{array}$ & $0.00^{*}$ \\
\cline { 2 - 3 } & $\begin{array}{l}\text { After } 2^{\text {nd }} \text { theory compared with } \\
\text { before } 1^{\text {st }} \text { theory }\end{array}$ & $0.00^{*}$ \\
\cline { 2 - 3 } & $\begin{array}{l}\text { After } 2^{\text {nd }} \text { theory compared with } \\
\text { After } 1^{\text {st }} \text { theory }\end{array}$ & $0.00^{*}$ \\
\hline \multirow{3}{*}{ Group-II } & $\begin{array}{l}\text { After theory compared with } \\
\text { before theory }\end{array}$ & $0.00^{*}$ \\
\cline { 2 - 3 } & $\begin{array}{l}\text { After PBL compared with before } \\
\text { theory }\end{array}$ & $0.00^{*}$ \\
\cline { 2 - 3 } & $\begin{array}{l}\text { After PBL compared with After } \\
\text { theory }\end{array}$ & $0.00^{*}$ \\
\hline Group-II Vs. Group-I & $\begin{array}{l}\text { After PBL compared with After } \\
2^{\text {nd }} \text { Theory }\end{array}$ & $0.00^{*}$ \\
\hline
\end{tabular}

*statistically significant

The comparison of evaluation test marks after PBL and revision class of theory (After $2^{\text {nd }}$ theory) reveals that the mean \pm SD values are $15.75 \pm 1.19$ and $12.76 \pm 1.70$ respectively. The knowledge of learners was significantly increased after theory revision class and after PBL session when compared with before theory class and after theory class (p-values $0.00,0.00$, 0.00 ). But the knowledge level was higher in the after PBL session when compared with after theory revision class ( $p$-values 0.00 ).

\section{DISCUSSION}

Educators are struggling to find practical instructional methods to promote critical inquiry and sustainable self-directed learning [11-15]. PBL has been heavily promoted in the literature and in educational conferences as the preferred method of promoting critical inquiry. This study assessed the outcomes of a major, similar curricular shift at two academic medical centers to examine methods to promote inquiry and development of related skills. The study reveals that the PBL system helps developing student skills particularly problem solving skills and help sharpen analytical skills. The majority of respondents agreed that PBL is better than the traditional system and consider it superior to the traditional Lecture-Based System in Medical Education. However, the teaching/learning facilities including audio-visual, reference books and Internet need further improvement.

The PBL process tends to become ritualized, with students skipping the stage of elaboration of prior knowledge. The discussion in the second session is reduced to presentation of the main results, with no attempts being made to appraise opinions and synthesize findings. Students shirk their responsibility to take an active part in the discussion out of lack of interest, laziness and uncertainty as has been found in some similar studies [16, 17] Students are satisfied with many objectives of the Problem Based Learning depicted comprehensively in the respective Blocks designed by the tutors and finalized by experts.

By clearly specifying the educational outcomes in behaviorally measurable ways, we can change the way faculty teach and students learn. Where evaluation drives the curriculum, graduation should contingent upon demonstrating mastery of a defined set of competencies [18]. In several of the Clerkship performance measures, the PBL students performed significantly better and in no circumstances did they perform worse than the standard curriculum [19]. The appropriate training for both faculty and students is an essential factor to ensure the successful implementation of PBL programme in medical schools especially for the topics which are deemed important and must know for the students.

This study reveals that the quality of implementation of curriculum and assessment methods needs to be improvised. Concept maps are suitable for quality management in education, thus enabling the paradigm shift in medicine. A series of communication, education, practice, system reforms and the PBL curriculum are required for the success of programme. Curriculum maps need to be developed for the smooth functioning of PBL system. Cultural issues including language problems in setting ground rules for PBL tutorials must be given due consideration. There is a strong need for well trained teachers who can conduct small group PBL sessions skillfully. Assessment methods of the students need to be consistent with how students learn.

\section{CONCLUSION}

In the learning process the application of PBL process is a significant challenge. Our study concludes that Students who used the problembased learning method showed better understanding of the subject and it encouraged 
active student participation in the learning process. A series of communication, education, practice, system reforms and the PBL curriculum are required for the success of programme.

\section{REFERENCES}

[1]. Jesus A., Cruz A., Gomes M. J. Case Based, Learner Centered Approach to Pharmacotherapy. Proceedings from EDULEARN 2011 (pp. 6074-6080). Presented at the Edulearn 2011, Barcelona: IATED.

[2]. Heale J, Davis D, Norman G, Woodward CA, Neufeld $V$, Dodd P. A randomized controlled trial assessing the impact of problem-based $v$ didactic teaching methods in CME. Proc Annu Confer Res Med Edu. 27:72-77.

[3]. Distlehorst LH, Dawson E, Robbs RS, Barrows HS. Problem-based learning outcomes: the glass halffull. Acad Med. 2005;80:294-299.

[4]. Barrows HS. A taxomony of problem-based learning concepts. Med Educ. 1986;20:481-486.

[5]. Maudsley G. Do we all mean the same thing by problem-based learning? A review of the concepts and formulation of the ground rules. Acad Med. 1999;74:178- 185.

[6]. Slavin SJ, Wilkes MS, Usatine R. Doctoring III. Innovations in education in the clinical years. Acad Med. 1995;70:1091-1095.

[7]. Dewey, J. EBook. 852. Democracy And Education. 2008:July 26.

[8]. Cisneros R. M., Salisbury-Glennon, J. D., AndersonHarper, H. M. Status of Problem- Based Learning Research in Pharmacy Education: A Call for Future Research. American Journal of Pharmaceutical Education, 2002:66(1);19-26.

[9]. Neufeld, V. R., Barrows, H. S. The "McM aster Philosophy": an approach to medical education. Journal of Medical Education. 1974:49(11);104050.

How to cite this article: Montosh Chakraborty, Shivakrishna Gouroju, Pinki Garg, Karthikeyan P. PBL: An Effective Method Of Reinforcement Learning. Int J Intg M ed Sci 2015;2(6):134-138. DOI: 10.16965/ijims.2015.119
[10].Barrows, H. S. A taxonomy of problem-based learning methods. Medical Education. 1986:20(6):481-6.

[11]. Evensen D. H., Salisbury-Glennon, J. D., Glenn, J. A qualitative study of six medical students in a problem-based curriculum: Toward a situated model of self-regulation. Journal of Educational Psychology.2001:93(4);659-76.

[12]. Roberts C, Lawson M, Newble D, Self A, Chan P. The introduction of large class problem-based learning into an undergraduate medical curriculum: an evaluation. Med Teach. 2005;27:52-53.

[13]. Barrows HS. A taxomony of problem-based learning concepts. Med Educ. 1986;20:481- 6.

[14].Wilkes MS, Usatine R, Slavin S, Hoffman JR. Doctoring: University of California, Los Angeles. Acad Med. 1998;3:32-40.

[15]. M ainemelis C, Boyatzis RF, Kolb DA. Learning styles and adaptive flexibility. Management Learning. 2002;33:5-33.

[16]. Dolman DH, Wolfhagen HA, Van Der Vleuten CP and Wijan WH. Solving Problems with Group Work in PBL: hold on to the philosophy. Medical education. 2001;35:884-889.

[17]. Jos M oast, Herma Robertson, Hans Savelberg \& Angelinque DE Rij K. Revitalising PBL Groups: Evaluating PBL with Study Teams. Education for Health 2005:18(1):62-73.

[18]. Stephen, Smith \& Richard Dollase. AM EE Guide No. 14: Oubased Education Part 2 - Planning, Implementing \& Evaluating a Competency Based Curriculum. Medical Teachers. 1999;21(1):15-19.

[19]. Distelhorst LH, Dawson E, Robbs RS, Borrows HS. PBL Outcomes: the glass is half full. Acad Med. 2005;80(3):294-99. 